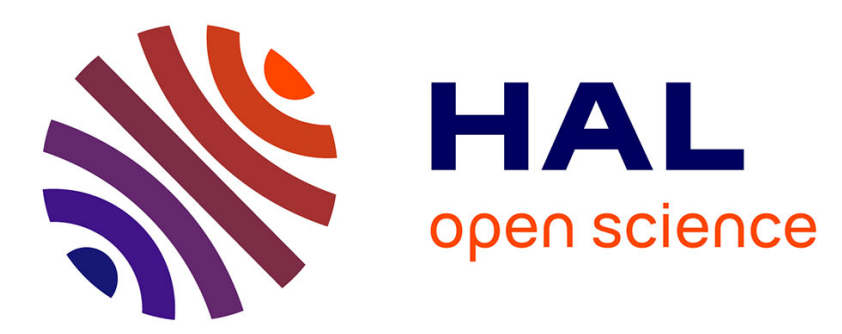

\title{
Development of the PACTITER code and its application to safety analyses of ITER Primary Cooling Water System
}

L. Di Pace, F. Dacquait, P. Schindler, V. Blet, F. Nguyen, Y. Philibert, B. Larat

\section{To cite this version:}

L. Di Pace, F. Dacquait, P. Schindler, V. Blet, F. Nguyen, et al.. Development of the PACTITER code and its application to safety analyses of ITER Primary Cooling Water System. Fusion Engineering and Design, 2006, 82 (3), pp.237-247. 10.1016/j.fusengdes.2006.11.002 . cea-02356047

\section{HAL Id: cea-02356047 https://hal-cea.archives-ouvertes.fr/cea-02356047}

Submitted on 2 Dec 2019

HAL is a multi-disciplinary open access archive for the deposit and dissemination of scientific research documents, whether they are published or not. The documents may come from teaching and research institutions in France or abroad, or from public or private research centers.
L'archive ouverte pluridisciplinaire HAL, est destinée au dépôt et à la diffusion de documents scientifiques de niveau recherche, publiés ou non, émanant des établissements d'enseignement et de recherche français ou étrangers, des laboratoires publics ou privés. 


\title{
Development of the PACTITER code and its application to safety analyses of ITER Primary Cooling Water System
}

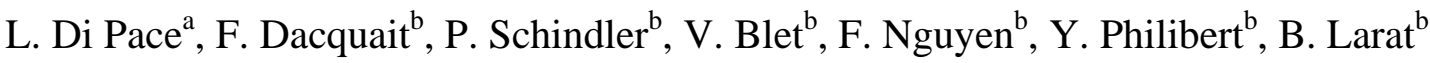

${ }^{a}$ Associazione Euratom-ENEA sulla Fusione, Via Enrico Fermi 45, 00044 Frascati, Italy, di_pace@frascati.enea.it

${ }^{b}$ CEA/DEN/DTN, Cadarache, 13108 St Paul lez Durance Cedex France

Corresponding author: L. Di Pace; $\quad$ Tel. :+39-0694005321; Fax : +39-0694005314;

\begin{abstract}
The PACTITER code derives from the PACTOLE code, developed by the CEA for predicting Activated Corrosion Products (ACPs) in PWR primary circuits. The operating conditions, material compositions and water chemistry of the various Primary Heat Transfer Systems (PHTS) of the International Thermonuclear Experimental Reactor (ITER) made mandatory the adaptation of the PACTOLE code. PACTITER was developed on the basis of dedicated experiments, namely devoted to determine copper solubility and stainless steel release in the ITER primary cooling systems conditions, which are rather different from those in PWR (i.e. water chemistry and temperatures). The PACTITER code has been extensively used in support of the ITER Generic Site Safety Report (GSSR) in the field of accident analysis and worker collective dose assessment.
\end{abstract}

Keywords: ITER, safety analysis, ACPs, PACTITER, PACTOLE 


\section{Introduction}

For almost 30 years, the PACTOLE code has been developed by the Commissariat à l'Energie Atomique (CEA) to predict the formation, activation, migration and deposition of corrosion products in the PWR primary system [1, 2]. The other main purpose of the code application is estimating the effects of changes in primary system design and operating parameters. The PACTOLE code has been validated by comparison between simulations and more than 30 years of contamination measurements on PWRs $[3,4]$. After an initial use of PACTOLE code, made by simply adapting the input to the ITER Primary Heat Transfer System (PHTS) characteristics, it was necessary to modify it and develop PACTITER to take into the presence of Cu-alloy as a new material in contact with water in the divertor cooling circuit. Afterwards, the modified PACTOLE code, called PACTITER, has been used in support of the Non-Site Specific Safety Report -2 (NSSR-2) (1996-1998) and to the Generic Site Safety Report (1998-2003) for accident analysis and worker collective dose assessment. Indeed, the Activated Corrosion Products (ACPs) in the ITER PHTS can be of some concern as contributor to the source term of potential released activity to the environment in case of accident (LOCA for instance) and to the Occupational Radiological Exposure (ORE) during the normal operation of ITER.

Some dedicated experiments have been performed to acquire physical-chemical input data and validation data in PHTS conditions, particularly, in order to determine the corrosion product release term into the fluid due to the stainless steel corrosion in PHTS conditions, and the copper solubility in the ITER water chemistry conditions. 


\section{PACTOLE/PACTITER phenomenological model description}

In a PWR primary system or an ITER PHTS, the formation process of ACPs is very complex. It involves many different mechanisms that react among each other. The first mechanism is the uniform and generalized corrosion of metallic alloys. For stainless steel materials, this leads to the generation of a dual oxide layer: an inner compact layer (chromite) and an outer porous layer (ferrite). The inner layer is a passive oxide layer, which limits ion exchanges between metallic alloys and primary coolant but does not eliminate them: ions are released in the primary coolant. The quantities of released materials are small (of about several $\mathrm{mg} / \mathrm{dm}^{2} / \mathrm{month}$ ) and do not alter component soundness.

The primary coolant transports ions generated by the corrosion-release phenomenon or by oxide dissolution. When the coolant becomes supersaturated in corrosion products, ions can precipitate on the walls or in the bulk of the fluid to form particles. Particles are also generated by erosion processes. Transported by the primary coolant, particles are deposited inside the circuits or they can agglomerate. Dissolution and precipitation depend on the corrosion product equilibrium concentrations, which depend on coolant chemical treatment (pH, $\mathrm{H}_{2}$ concentration (or Redox potential), temperature). Two types of radioactive corrosion product formation coexist. On the one hand, the activation of corrosion products occurs when they are deposited on surfaces under neutron flux. On the other hand, the corrosion of structural materials under neutron flux is accompanied by a release of radioactive corrosion products. 
The PACTOLE and the PACTITER codes are based on a control volume approach, the primary circuit is represented by an arrangement of several volumes in which transient mass balance equations are solved :

$$
\frac{\partial \mathrm{m}_{\mathrm{i}}}{\partial \mathrm{t}}+\left(\dot{\mathrm{m}}_{\mathrm{s}}-\dot{\mathrm{m}}_{\mathrm{e}}\right)=\sum_{\text {Source }} \mathrm{J}_{\mathrm{m}}-\sum_{\text {Sink }} \mathrm{J}_{\mathrm{m}}
$$

Where $\mathrm{m}_{\mathrm{i}}$ is the mass of the $\mathrm{i}^{\text {th }}$ isotope in a considered medium defined as a form for the corrosion products, $\mathrm{t}$ is the time, $\dot{\mathrm{m}}_{\mathrm{s}}-\dot{\mathrm{m}}_{\mathrm{e}}$ is the convective term (balance between input and output) and except for nuclear reactions, which are mass production/loss within the

considered medium, $\mathrm{J}_{\mathrm{m}}$ is the exchange mass rate between two different media.

Seven different media are taken into account in a control volume and depicted in Figure 1. The transfer mechanisms, which are modelled in the mass balance equations, between all the considered media, are summarised in Figure 2.

The corrosion and release processes are formulated in the mass balance equations as functions of their time production rates. This formulation yields results on the consequences of material surface treatments, on the corrosion and release processes and, thus on the circuit contamination.

\section{Application of PACTOLE to ITER: the development of the PACTITER code}

The PACTITER code is currently being used for predicting the Activated Corrosion Product (ACP) inventory in the various ITER (International Thermonuclear Experimental Reactor) Primary Heat Transfer System (PHTS) circuits of the Tokamak Cooling Water System (TCWS) for accident analysis and personnel safety (ORE assessment). 
At the very beginning (1994-1996), the PACTOLE code was used for predicting activated corrosion products inventory and distribution in the first wall/shielding blanket cooling loops of the ITER PHTS [5, 6], by simply adjusting the input deck to the case. The major modifications in the PACTOLE input deck were directed at simulating the particular ITER PHTS operating conditions, which are quite different from those of PWRs. In PWRs, the coordinated B-Li chemistry is used to control a constant $\mathrm{pH}_{300}{ }^{\circ} \mathrm{C}$ to a target value of 7.2 characterized by the use of boric acid $\left(\mathrm{H}_{3} \mathrm{BO}_{3}\right)$ and $\mathrm{Li}$ hydroxide (LiOH) differently from ITER PHTS whose chemistry is closer to a Boiling Water Reactor water chemistry mainly controlled by its conductivity (less than $0.3 \mu \mathrm{S} / \mathrm{cm}$ ). The other main difference is the temperature range, which is $50-240{ }^{\circ} \mathrm{C}$ for ITER operation.

The other peculiarity of the ITER PHTS is the presence of copper alloys in the divertor cooling loops, that forced to consider a new element, copper, which was not included in PACTOLE. That required the realization of the new code PACTITER to include copper as the sixth element in addition to $\mathrm{Fe}, \mathrm{Ni}, \mathrm{Cr}, \mathrm{Co}$ and $\mathrm{Mn}$.

The three following nuclear reactions involving $\mathrm{Cu}$, found to be the most important ones for safety analysis, were then included in PACTITER:

$$
\begin{aligned}
& -\quad{ }^{63} \mathrm{Cu}(\mathrm{n}, \gamma){ }^{64} \mathrm{Cu} ; \\
& -\quad{ }^{65} \mathrm{Cu}(\mathrm{n}, 2 \mathrm{n}){ }^{64} \mathrm{Cu} ; \\
& -\quad{ }^{63} \mathrm{Cu}(\mathrm{n}, \alpha){ }^{60} \mathrm{Co} .
\end{aligned}
$$

First, a Cu solubility curve as a function of temperature was defined on the basis of data from a survey of the existing literature [7].

In parallel, an experimental campaign, performed by CEA Fontenay-aux-Roses, was launched in early 1996 to obtain Cu solubility data for ITER divertor PHTS conditions [8]. 
The ACP assessment for all ITER cooling loops were completed in early 1998 in support to NSSR-2, Volume III “Radiological and Energy Source Terms”. The ACP assessment was then repeated to take into account design modification in the PHTS design (e.g. the heat exchangers with primary coolant on the shell side) [9]. The comparison with experimental corrosion data related to ITER operating conditions and Cu-alloys provided a satisfactory result [8].

Further to the decision taken to update the ITER Final Design Report defined in 1998 (ITER FDR) to reduce size and cost of the machine still satisfying the overall programmatic objective of the ITER EDA (Engineering Design Activity), the machine design was reviewed including that of PHTS during the extension (1998-2001) of the EDA phase. The number of cooling loops of the PHTS was reduced from a total of 20 to 6. Again, the code PACTITER was applied to estimate the ACP inventory of the ITER PHTS according to the new design in support of accident analysis and worker collective dose assessment, with results documented in the Generic Site Safety Report (GSSR) [10].

\section{ITER safety requirements for ACPs}

ACPs will be present in ITER in the various in-vessel and vacuum vessel coolant loops as well as in any coolant loops related to test blanket modules, auxiliary heating or diagnostics equipment. These products impact occupational exposure, routine effluents to the environment, and potential releases during accidents. That has made the ACP inventory evaluation an important task for ITER public and occupational safety. ACPs present in fission reactors cooling loops do not pose a significant public hazard in these installations, however they are a significant hazard to site personnel. In fact, in case of severe accidents in LWRs, ACPs are negligible in terms of radioactive inventory, 
mobilisable inventory and environmental source term, compared to the analogous inventories from the reactor core (fission products and actinides). On the contrary for fusion devices such as ITER, ACPs could be important in terms of the whole mobilisable inventory in case of accidents compared to other major source terms, tritium and dust.

The enveloping ACPs inventory adopted for ITER accident analyses [11] was assumed to be $10 \mathrm{~kg} / \mathrm{loop}$ as deposit and $0.6 \%$ of deposit mass in the suspended forms (soluble ions or crud particulates), irrespective of the cooling loop type, first wall//shielding blanket, divertor or vacuum vessel.

The other important safety requirements are the project release guidelines for the ACPs, tritium and dusts as shown in Table 1. For the occupational radiation exposure (ORE) doses, the limits and project guidelines have been adopted [12] as shown in Table 2.

\section{ITER ACP assessment by PACTITER}

Many calculations were carried out by the PACTITER code to assess ACP in the PHTS of ITER TCWS, following the several evolutions of the design.

The PACTITER geometric model of one first wall/shielding blanket cooling loop of the ITER PHTS (according to the Final Design Report 2001) is depicted in Figure 3. The ACP assessment carried out for a single First Wall/Shield cooling loop provided a value of $1.8 \mathrm{~g}$ of suspended cruds and $10.9 \mathrm{~g}$ of dissolved ions. The total ACP deposit mass was $1.4 \mathrm{~kg} / \mathrm{loop}$. The hazard of the ACP is typically dominated by Mn-56 that arises from $\mathrm{Mn}$ and Fe in the base alloy steel, by Co-57 and Co-58, that arise from $\mathrm{Ni}$ in the base steel and by Co-60 that arises principally from Co in the base steel. The ACP deposit inventory is more than seven times lower than the limit of $10 \mathrm{~kg} / \mathrm{loop}$ while the ACP inventory in the suspended forms is about 5 times lower than the limit. The ACP 
assessment for the divertor cooling loop provided values closer to the limits, $8.9 \mathrm{~kg}$ for the deposit mass and $42 \mathrm{~g}$ in the suspended forms. The ACP inventory for VV loops was estimated to be $6 \mathrm{~kg} / \mathrm{loop}$ for mass deposit and $25.6 \mathrm{~g} / \mathrm{loop}$ in the suspended forms. The estimated base metal release rates for the different cooling loops of the ITER PHTS are shown in Table 3.

Mass release rates of the VV loop stainless steels are lower due to the lower coolant operating temperature $\left(100-103^{\circ} \mathrm{C}\right)$ and to the lower coolant velocity $(<0.5 \mathrm{~m} / \mathrm{s})$ in most regions of the loop.

ACP mass and activity inventory were used in accident analyses involving LOCA with consequent releases to the environment. Among several accident sequences analysed [13], a large DV ex-vessel coolant pipe break provided the largest ACP environmental release, equal to $1.2 \%$ of the project release guidelines (see Table 1 ). The ACP radioactive inventory distribution, assessed by the PACTITER code for ITER PHTS, was used to determine the dose rates around its system components (e.g. piping, main pumps, valves, heat exchangers) during scheduled and unscheduled maintenance. Starting from the radiation field and taking into account the anticipated work effort, the related annual collective ORE was estimated to be 65 pers $\cdot \mathrm{mSv}$ [14] for the first wall/shield loops (30 pers·mSv) and divertor loop (35 pers·mSv). The contribution from VV loops was not estimated being the related ACP radiation hazard negligible compared to the other loops, as written before.

\section{Experimental activity in support of PACTITER development and validation}

Two main experimental activities were set up and carried out aiming at the development and validation of PACTITER. 
The first one, launched in 1996 was performed at CEA Fontenay-aux-Roses, to get $\mathrm{Cu}$ solubility data in the ITER divertor PHTS conditions.

The second one was carried out at CEA Cadarache in two phases (2001 and 2004) to study the ACP release mechanism in close ITER coolant chemistry, temperature and velocity conditions. Both are described in more detail in the following sections.

\section{Copper solubility data in ITER divertor PHTS conditions}

The experimental campaign, performed by CEA Fontenay-aux-Roses, was launched in early 1996 to get Cu solubility data in the ITER divertor PHTS conditions [15]. This experimental study was devoted to determine the valence states of the copper $\left(\mathrm{Cu}^{0}, \mathrm{Cu}^{+}\right.$ or $\mathrm{Cu}^{++}$) and to obtain solubility in steady state conditions. In order to check the stable phases of $\mathrm{Cu}$ in ITER divertor coolant conditions, autoclave tests were performed on copper and copper oxides. These included four tests at 100 and $250{ }^{\circ} \mathrm{C}$ on $\mathrm{CuO}$ and $\mathrm{Cu}_{2} \mathrm{O}$, pure copper and $\mathrm{Cu}-\mathrm{Cr}-\mathrm{Zr}$ (the reference $\mathrm{Cu}$ alloy for ITER divertor high heat flux components).

The major findings of this part of the study were:

- In reducing conditions, stable phase is $\mathrm{Cu}^{0}$, dissolution can occur according to the chemical reaction:

$$
\mathrm{Cu}_{(\mathrm{s})}^{0}+\mathrm{H}_{(\mathrm{aq})}^{+} \Leftrightarrow \mathrm{Cu}_{(\mathrm{aq})}^{+}+1 / 2 \mathrm{H}_{2(\mathrm{~g})}
$$

- $\quad$ Kinetics of reduction from $\mathrm{Cu}^{\mathrm{I}}$ and/or $\mathrm{Cu}^{\mathrm{II}}$ to $\mathrm{Cu}^{0}$ is very slow.

The other part of the experimental campaign was devoted to determine the total concentration of soluble copper in equilibrium with $\mathrm{Cu}-\mathrm{Cr}-\mathrm{Zr}$ alloy in chemical conditions close to those of the ITER divertor primary coolant. The solubility 
measurements were carried out in a flow device made of titanium. The measured $\mathrm{pH}$ during all the tests was in the range of $6.4 \pm 0.2$.

The solubility measurements, illustrated in Figure 4 [8], are quite different from those obtained from the literature [7]. The copper concentrations determined by tests are four or five orders of magnitude larger than the copper solubility obtained by thermodynamic data. Such difference could be explained by:

- the formation of copper colloids during tests;

- the presence of another Cu species, such as copper oxides previously formed during the exposure to vapours at room temperature or before establishing reducing conditions;

- the oxidation of $\mathrm{Cu}$ due to the existence of oxygen traces in water (copper is known as a very good getter of oxygen).

\section{ITER ACP release mechanism}

In order to get realistic values of release kinetics and thus to improve the understanding of ACP generation, experiments have been carried out in 2001 and 2004 using the CORELE loop (see Figure 5) in thermalhydraulics operating conditions envisaged for ITER PHTS and with the chemistry given in Table 4.

Having circulated in the irradiated tubes, the coolant (deionized water) is purified by passing through mixed beds of ion-exchange resins (Figure 5). No release can exist in the loop [cold part in polypropylene, hot part in zircaloy], except in the test sections. Then, all the released ions are radioactive and trapped in the measurement ion-exchange resins. The nature and quantity of these radio nuclides are then determined by gamma spectrometry of the resins. 
All the tubes considered in this study are made of 316 L Stainless Steel whose composition (given in Table 5) is close to an ITER Grade 316L SS.

The detected ${ }^{58} \mathrm{Co},{ }^{59} \mathrm{Fe},{ }^{54} \mathrm{Mn}$ and ${ }^{51} \mathrm{Cr}$ radio nuclides are then assumed to be representative of the main elements of the steel from whom they are generated (see Table 6). In the case of ${ }^{59} \mathrm{Fe}$ and ${ }^{54} \mathrm{Mn}$, both can be considered as tracers of iron justifying the fact that the release rate of Fe is taken as the mean value of the ${ }^{59} \mathrm{Fe}$ release rate and the ${ }^{54} \mathrm{Mn}$ release rate.

For each chemical species, the release rate $\mathrm{R}\left(\mathrm{mg} / \mathrm{dm}^{2} / \mathrm{month}\right)$ is calculated using the following expression:

$$
\mathrm{R}=\frac{\mathrm{A} \cdot \mathrm{W}}{\mathrm{A}_{\mathrm{w}} \cdot \mathrm{S} \cdot \mathrm{T}}
$$

where :

- $\quad$ A : Activity $(\mathrm{Bq})$ of radionuclide in measurement resin at time $t$ corresponding to the beginning of the experiment i.e. when the temperature in CORELE is reached and the coolant flows through the test sections. Actually, this activity is measured at the end of the experiment by disconnecting the measurement resins from the circuits of the loop and placing them in a dedicated device. This device enables the gamma spectrometry of the resins in a low environmental background. The measured activity is then corrected from the radioactive decay in order to correspond to time $t$.

- $\quad \mathrm{w}$ : weight $\%$ of the element in the tube (mg/mg of tube) (manufacturer's data).

- $\quad \mathrm{A}_{\mathrm{w}}$ : specific activity of tracing radionuclide in the tube at time $t(\mathrm{~Bq} / \mathrm{mg}$ of tube). This activity is deduced from the measurement at the date of irradiation corrected from the radioactive decay in order to correspond to time $t$.

- $\quad \mathrm{S}$ : Exchange surface of tube with primary coolant $\left(\mathrm{dm}^{2}\right)$. 
- $\quad \mathrm{T}$ : Duration of the test (month).

The global release rate is the sum of the different release rates relative to each radionuclide measured in the resins. They are summarized for each test in Table 7. The two first tests were performed with the same irradiated tubes although the last one was performed with new freshly irradiated pair of tubes. The Li content, introduced as $\mathrm{LiOH}$, was required due to the fact that the used water was not perfectly deionized and slightly acidic.

\subsection{Release of chromium}

Chromium was detected during the first test and was only trapped in measurement resin, thus indicating the presence of a soluble form of chromium. This detection could thus be linked to the temperature of the test $\left(150^{\circ} \mathrm{C}\right)$ and to the slight presence of oxygen which could favor the formation of a chromite layer $\left(\mathrm{Cr}_{2} \mathrm{O}_{3}\right.$ or $\mathrm{MCr}_{2} \mathrm{O}_{4}$, where $\mathrm{M}=\mathrm{Fe}$, Ni). The existence of such $\mathrm{MCr}_{2} \mathrm{O}_{4}$ layer is coherent with experimental results indicating the release of $\mathrm{Fe}$ and $\mathrm{Ni}$ (upon the assumption that ${ }^{58} \mathrm{Co}$ is representative of $\mathrm{Ni})$. It is worth noting that when the temperature is lower $\left(100^{\circ} \mathrm{C}\right)$, no soluble chromium is detected when the $\mathrm{O}_{2}$ content in the fluid is less than $24 \mathrm{ppb}$.

\subsection{Influence of temperature}

Globally, it can be seen that the lower the temperature, the lower the release rate in the tested range. These results could be explained by the existence of a diffusion barrier (possibly as a chromite) at the interface fluid/stainless steel. At low temperature (say less than $100^{\circ} \mathrm{C}$ ), the solid diffusion of atomic oxygen in this layer could be 
considerably reduced, thus limiting the further formation of oxides (corrosion), and then the associated releases. As an example, the thickness of a $\mathrm{Cr}_{2} \mathrm{O}_{3}$ layer is commonly of the order of a nanometer $\left(\mathrm{L}=10^{-9} \mathrm{~m}\right)$. Considering a solid diffusion coefficient, $\mathrm{D}$, of $10^{-}$ ${ }^{21} \mathrm{~m}^{2} / \mathrm{s}$ (common value) leads to a characteristic diffusion time $\left(\mathrm{L}^{2} / \mathrm{D}\right)$ of 20 minutes compared to more than 300 hours of duration of the tests. Dividing D by 1000 when T is decreased from $150^{\circ} \mathrm{C}(423 \mathrm{~K})$ to $100^{\circ} \mathrm{C}(373 \mathrm{~K})$ could be possible if the activation energy would be higher than $180 \mathrm{~kJ} / \mathrm{mol}$.

\subsection{Influence of velocity}

From the comparison of the different tests conducted at about $1 \mathrm{~m} / \mathrm{s}$ and $4 \mathrm{~m} / \mathrm{s}$ (at the same temperature), one can conclude that the lower the velocity, the slightly higher the release rate. Note that the difference in velocity is obtained by a reduction in the hydraulic diameter thanks to an insert inside the test section.

The velocity is a key parameter in the release global process as it is responsible for erosion of the deposits and for mass transfer limitation in the hydraulic diffusion layer. The erosion depends directly on the velocity whatever the temperature and the wall roughness in the tests conditions. No particles having been detected: one must conclude that, in these last 2004 tests conditions, erosion is not a relevant mechanism. On another hand, the mass transfer coefficient in the diffusion layer is given through the Nusselt number calculated, for instance, by the Dittus-Boelter correlation (see Table 8). It appears that an increase in coolant velocity due to the reduction in the hydraulic diameter globally decreases the mass transfer - and then the release rate.

Finally, two types of mass transfer limitations can be put forward in these ITER-like PHTS conditions : 
$>$ the thermally activated solid diffusion of oxygen in a surface barrier (possibly as a chromite) which reduces the potential source of release by corrosion,

the hydraulic diffusion which depends solely on Reynolds number instead of the velocity.

\section{Conclusions}

The application of the PACTITER code to the prediction of ACP for fusion reactors has been ongoing for more than 10 years. The extensive work of development, qualification and validation through dedicated experiments, and application of PACTITER to ACP assessment, mainly for ITER safety analyses (release in accident conditions and occupational dose to the staff), has produced valuable results. The ultimate aim is to further reduce the uncertainties in the source terms considering the specific material and operating scenarios of ITER machine. This effort will also fulfill some of the requirements for ITER licensing in Europe.

\section{Acknowledgements}

This work, supported by the European Communities under the Contract of Association between EURATOM on one side and CEA / ENEA on the other side, was carried out within the framework of the European Fusion Development Agreement. The views and opinions expressed herein do not necessarily reflect those of the European Commission. 


\section{References}

1 P. Beslu, G. Fréjaville, A. Lalet, “A computer code PACTOLE to predict activation and transport of corrosion products in a PWR”, Proceedings of the International conference of water chemistry of nuclear reactor systems 1, 24-27/10/77, Bournemouth (GB), p. 195-201, BNES, London

2 F. Nguyen, H. Marteau, F. Dacquait, N. Perot, G. Ranchoux, L. Guinard, A. Long, "First numerical simulations of contamination of the PWR primary circuit by activated corrosion products with the PACTOLE V3.0 code”, Proceedings of the International conference on Water chemistry in nuclear reactors systems, October $11^{\text {th }}-14^{\text {th }}$, San Francisco USA, (2004)

3 J.C. Robin, F. Joyer, S. Anthoni, "Validation et qualification du code PACTOLE V2 (Validation and qualification of the PACTOLE V2 code)”, CEA Technical Note

\section{DEC/SECA/LCC 95-236}

4 J.C. Robin, F. Coulet, P. Beslu, P. Ridoux, A. Long, " PACTOLE: A Computer Code to Predict the Activation and Transport of Corrosion Product in PWRs"; Proceedings of the International Symposium on Activity Transport in Water Cooled Nuclear Power Reactors, Ottawa (Canada), 1994 October 24-25

5 L. Di Pace, G. Cambi, D. G. Cepraga, E. Sobrero, M. Costa, “Activated corrosion products in ITER first wall and shielding blanket heat transfer system”, Proceedings of 16th Symposium on Fusion Engineering, Urbana, Illinois, USA (1995)

6 S. Nisan, L. Di Pace, J-C. Robin, "Evaluation of the Activated Corrosion Product Source Term for ITER Heat Transfer System”, Fusion Technology 1996, Proceedings of 19th Symposium on Fusion Technology, Elsevier, (1996) p.1871-1874 
7 S. Eriksson, L. Permer, Aqueous Corrosion of Copper Alloys - Literature Survey, ITER task CTA-EU-T10, Studsvik, (1995)

8 L. Di Pace, D. Tarabelli, D. You, "Development of the PACTITER code and its application to the assessment of the ITER Divertor cooling loop corrosion products”, Fusion Technology 34, No. 3 part 2, (1998) p. 733-737

9 L. Di Pace, D.G. Cepraga, “Final report on Activated Corrosion Products Evaluation for the ITER-FDR PHTS”, ERG-FUS TN SIC 12/99, (1999)

10 ITER Generic Site Safety Report, Volume III, IDoMS G 84 RI 3 01-07-13 R1.0, (2001)

11 ITER Safety Analysis Data List, Vers. 4.0.1, IDoMS G 81 RI 10 03-08-08 W 0.1 (2003)

12 ITER Generic Site Safety Report, Volume I, IDoMS G 84 RI 1 01-07-09 R 1.0, (2001)

13 ITER Generic Site Safety Report, Volume VII, IDoMS G 84 RI 6 01-07-10 R 1.0, (2001)

14 ITER Generic Site Safety Report, Volume VI, IDoMS G 84 RI 6 01-07-10 R 1.0, (2001)

15 D. You, S. Lefevre, P. Gerlinger, A. Chenière, “Thermodynamic stability and solubility of copper and copper oxides”, CEA Tech. Report SCECF 420, (1997) 


\section{Captions}

Figures:

Figure 1 : Media in a Control Volume for a PACTOLE representation

Figure 2 : Transfer processes between media in a control volume

Figure 3 : PACTITER geometric model of one first wall/shielding blanket cooling loop of the ITER PHTS

Figure 4 : Cu concentration in steady state conditions, comparison of experiments data [6] and literature data [5]

Figure 5 : The CORELE Loop

Tables:

Table 1 - ITER project release guidelines [10]

Table 2 - ITER limits and project guidelines for ORE doses

Table 3 - ITER PHTS cooling loop material average release rate

Table 4 - Operating conditions for simulated ITER tests in the CORELE loop

Table 5 - CORELE test - Composition of the used SS316L tubes

Table 6 - CORELE test - Activation products of the main elements of the tubes

Table 7 - CORELE test - Measured release rates

Table 8 - CORELE test - Thermal-hydraulic parameters 
Figure 1

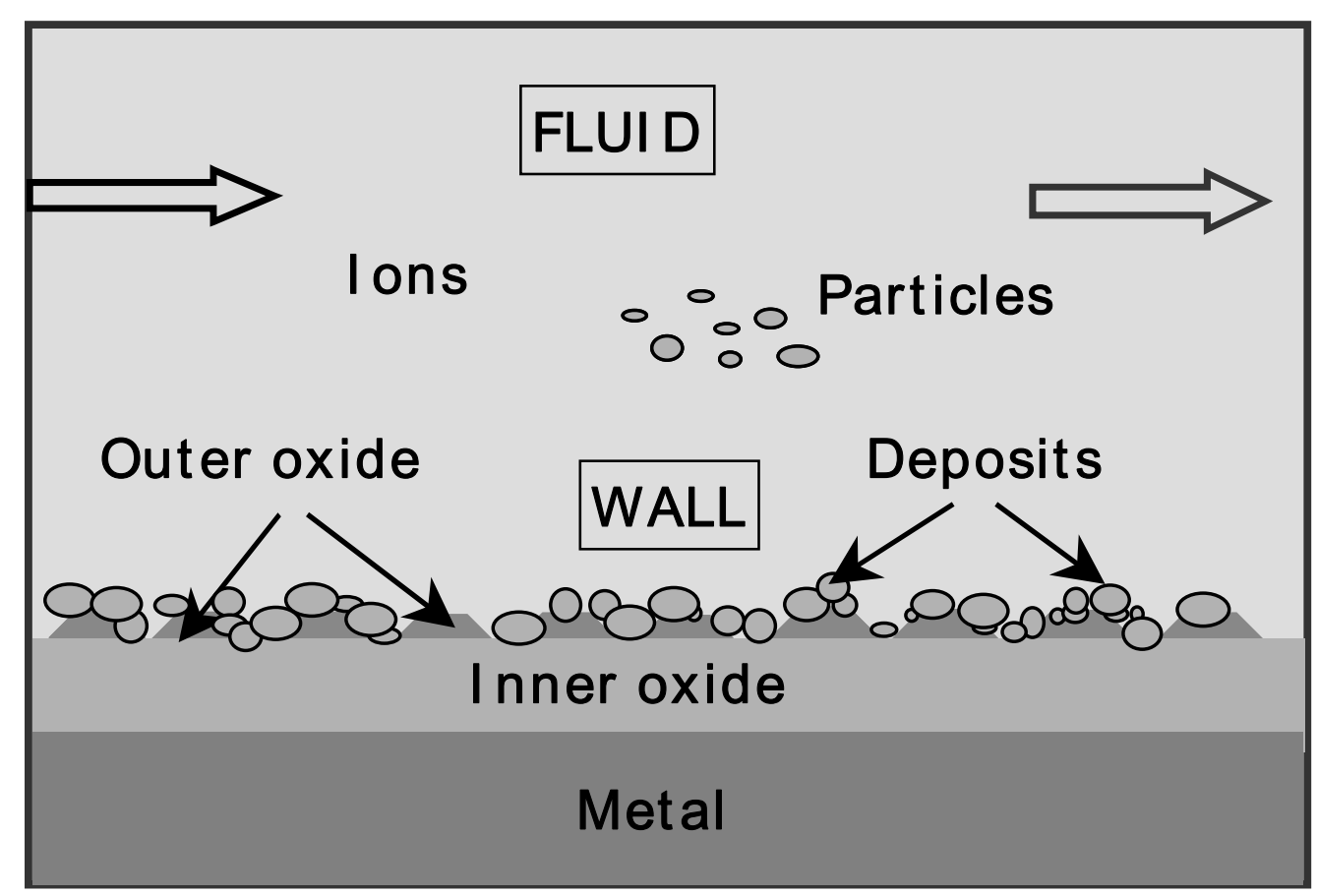


Figure 2

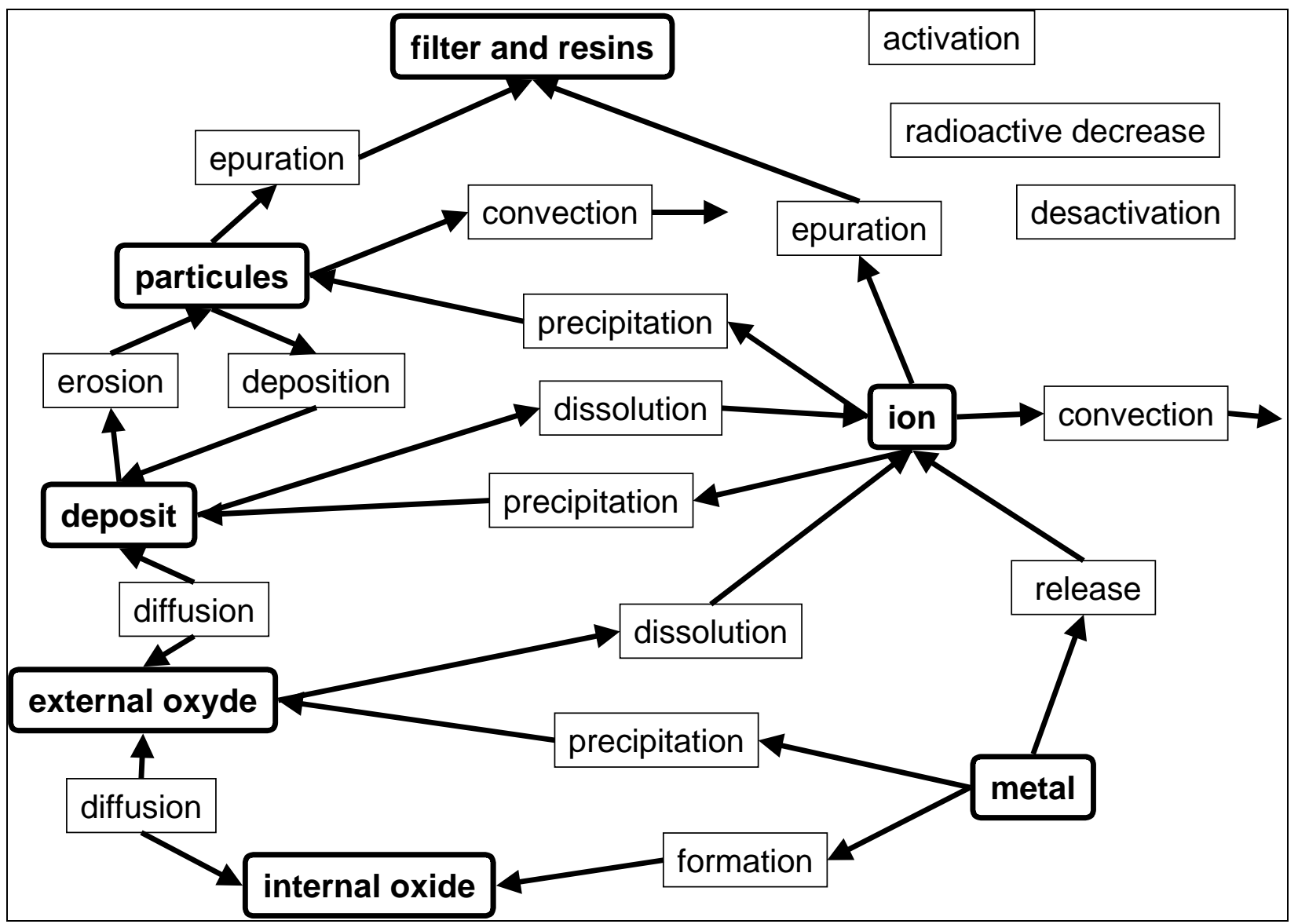


Figure 3

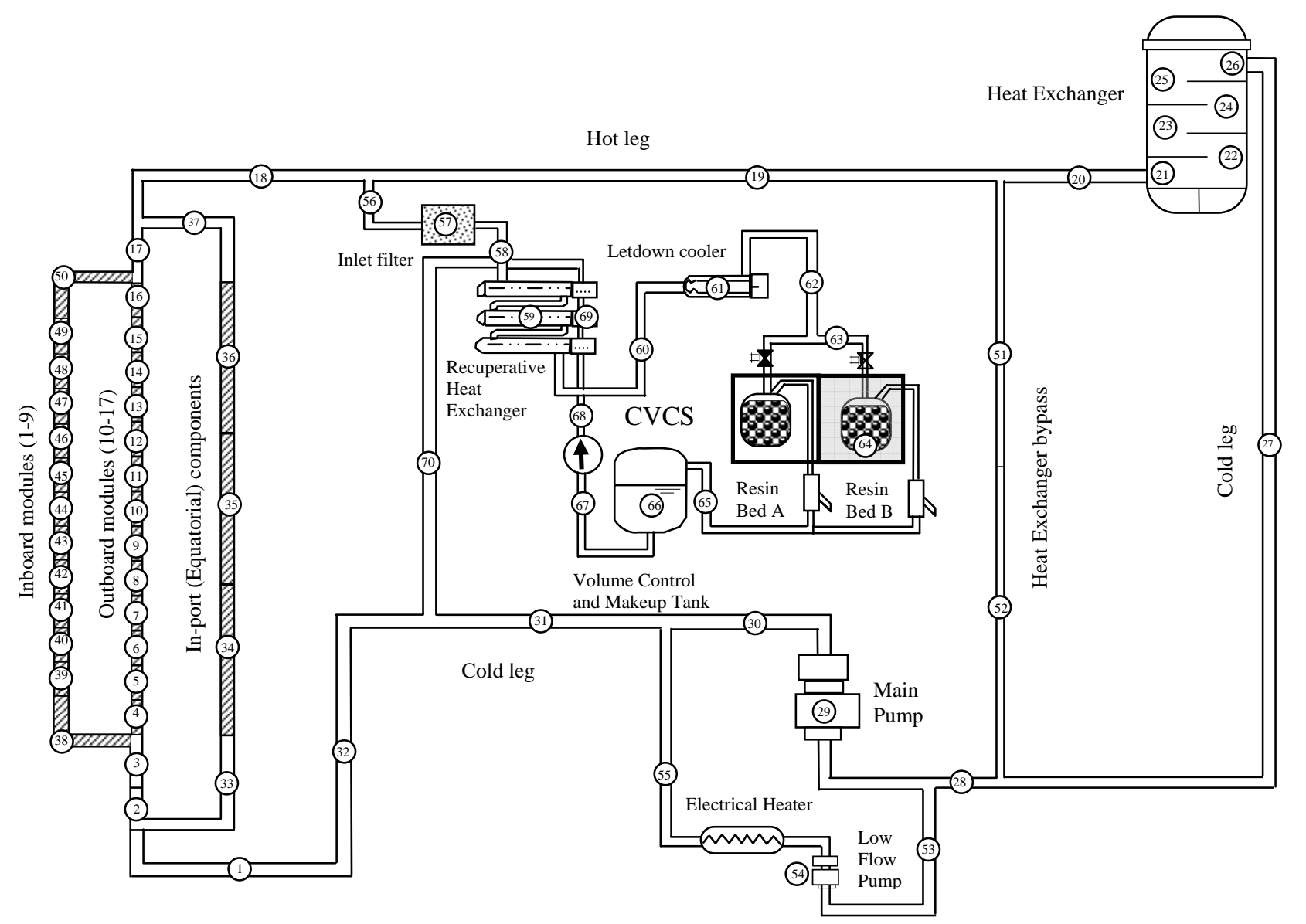


Figure 4

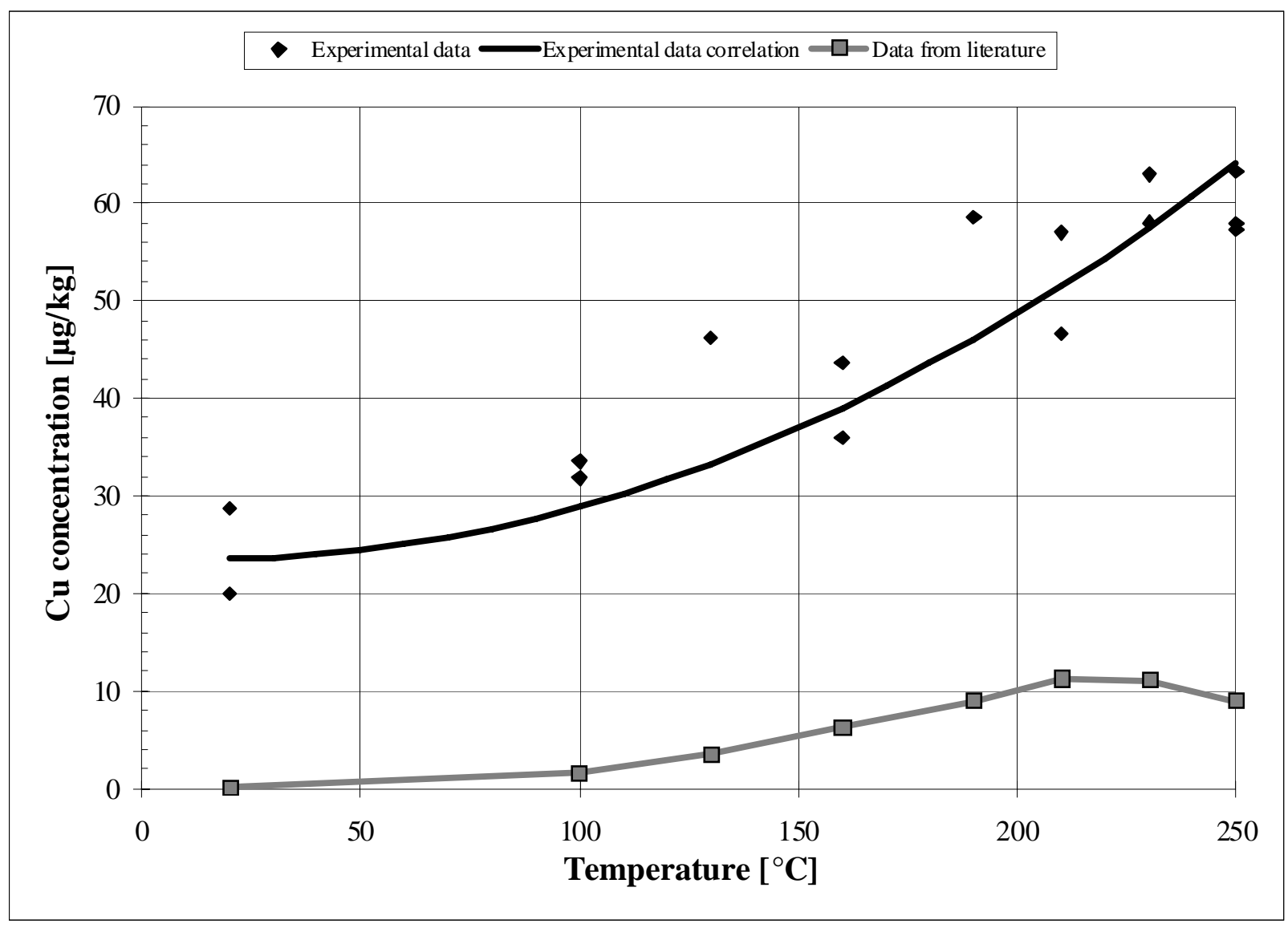


Figure 5

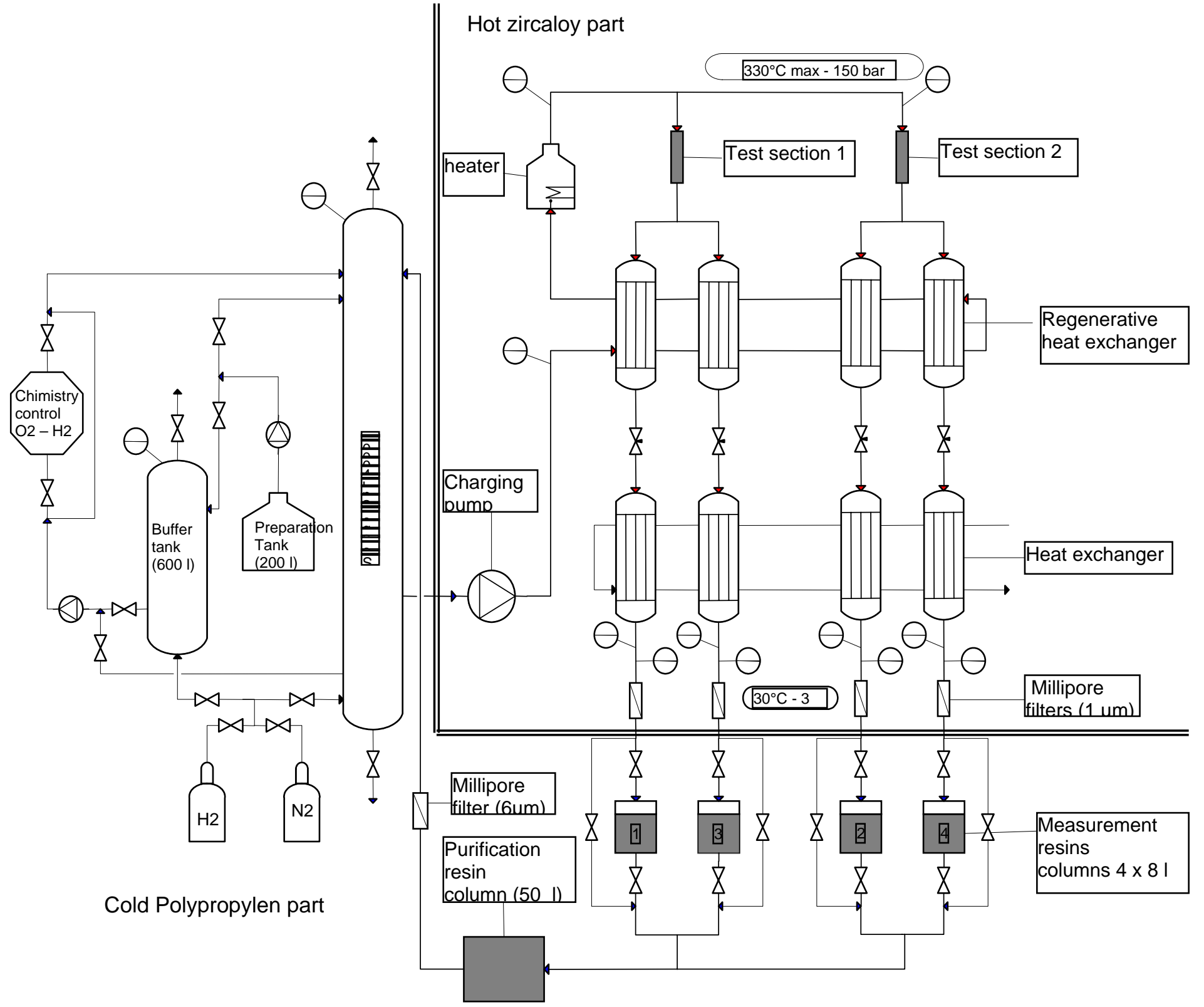


Table 1 - ITER project release guidelines [10]

\begin{tabular}{|c|c|}
\hline Events or Conditions & Project Release Guideline(*) \\
\hline $\begin{array}{l}\text { Normal Operation } \\
\text { event sequences and plant conditions planned and } \\
\text { required for ITER normal operation, including } \\
\text { some faults, events or conditions which can occur } \\
\text { as a result of the ITER experimental nature }\end{array}$ & $\begin{array}{l}<1 \mathrm{~g}-\mathrm{T} \text { as } \mathrm{HT} \text { and } 0.1 \mathrm{~g}-\mathrm{T} \text { as HTO } \\
\text { and } 1 \mathrm{~g} \text {-metal as AP and } 5 \text { g-metal } \\
\text { as ACP per year. }\end{array}$ \\
\hline $\begin{array}{l}\text { Incidents } \\
\text { deviations from normal operation, event } \\
\text { sequences or plant conditions not planned but } \\
\text { likely to occur due to failures one or more times } \\
\text { during the life of the plant but not including } \\
\text { Normal Operation }\end{array}$ & $\begin{array}{l}<1 \mathrm{~g}-\mathrm{T} \text { as HT or } 0.1 \mathrm{~g}-\mathrm{T} \text { as HTO } \\
\text { or } 1 \text { g-metal as AP or } \mathbf{1} \text { g-metal as } \\
\text { ACP or equivalent combination of } \\
\text { these per event }\end{array}$ \\
\hline $\begin{array}{l}\text { Accidents } \\
\text { postulated event sequences or conditions not } \\
\text { likely to occur during the life of the plant. }\end{array}$ & $\begin{array}{l}<50 \text { g-T as HT or } 5 \text { g-T as HTO or } \\
50 \text { g-metal as AP or } \mathbf{5 0} \text { g-metal as } \\
\text { ACP or equivalent combination of } \\
\text { these per event. }\end{array}$ \\
\hline
\end{tabular}

Note: (*) HT: elemental tritium (including DT); HTO: tritium oxide (including DTO); AP: divertor or first-wall activation products; ACP: activated corrosion products. 
Table 2 - ITER limits and project guidelines for ORE doses

\begin{tabular}{|l|l|}
\hline \multicolumn{2}{|l|}{ Dose Limits } \\
\hline ICRP recommended limit for annual & $20 \mathrm{mSv}$ averaged over 5 years not to \\
exceed $50 \mathrm{mSv}$ in any year \\
\hline Project Guidelines & $5 \mathrm{mSv} / \mathrm{year}$ \\
\hline Annual individual worker doses & $0.5 \mathrm{mSv} / \mathrm{shift}$ \\
\hline Individual worker dose for any given & \\
shift
\end{tabular}


Table 3 - ITER PHTS cooling loop material average release rate

\begin{tabular}{||l|l|l|l|l||}
\hline Cooling loop type & $\begin{array}{c}\text { Scenario } \\
\text { duration } \\
\text { [days] }\end{array}$ & $\begin{array}{c}\text { SS316L } \\
\text { release rate } \\
{[\mu \mathrm{m} / \text { year] }}\end{array}$ & $\begin{array}{c}\text { SS304L }\left(^{\circ}\right) \\
\text { release rate } \\
{[\mu \mathrm{m} / \text { year] }}\end{array}$ & $\begin{array}{c}\text { Cu-alloy } \\
\text { release rate } \\
{[\mu \mathrm{m} / \text { year] }}\end{array}$ \\
\hline FW/shield & 3681 & 0.16 & 0.07 & $\left(^{*}\right)$ \\
\hline Divertor & 3681 & 0.16 & 0.11 & 2.18 \\
\hline VV & 3681 & 0.008 & 0.047 & $\left(^{*}\right)$ \\
\hline
\end{tabular}

$\left(^{\circ}\right)$ material in the non-irradiated zones $\left(^{*}\right)$ no Cu-alloy in this cooling loop 
Table 4 - Operating conditions for simulated ITER tests in the CORELE loop

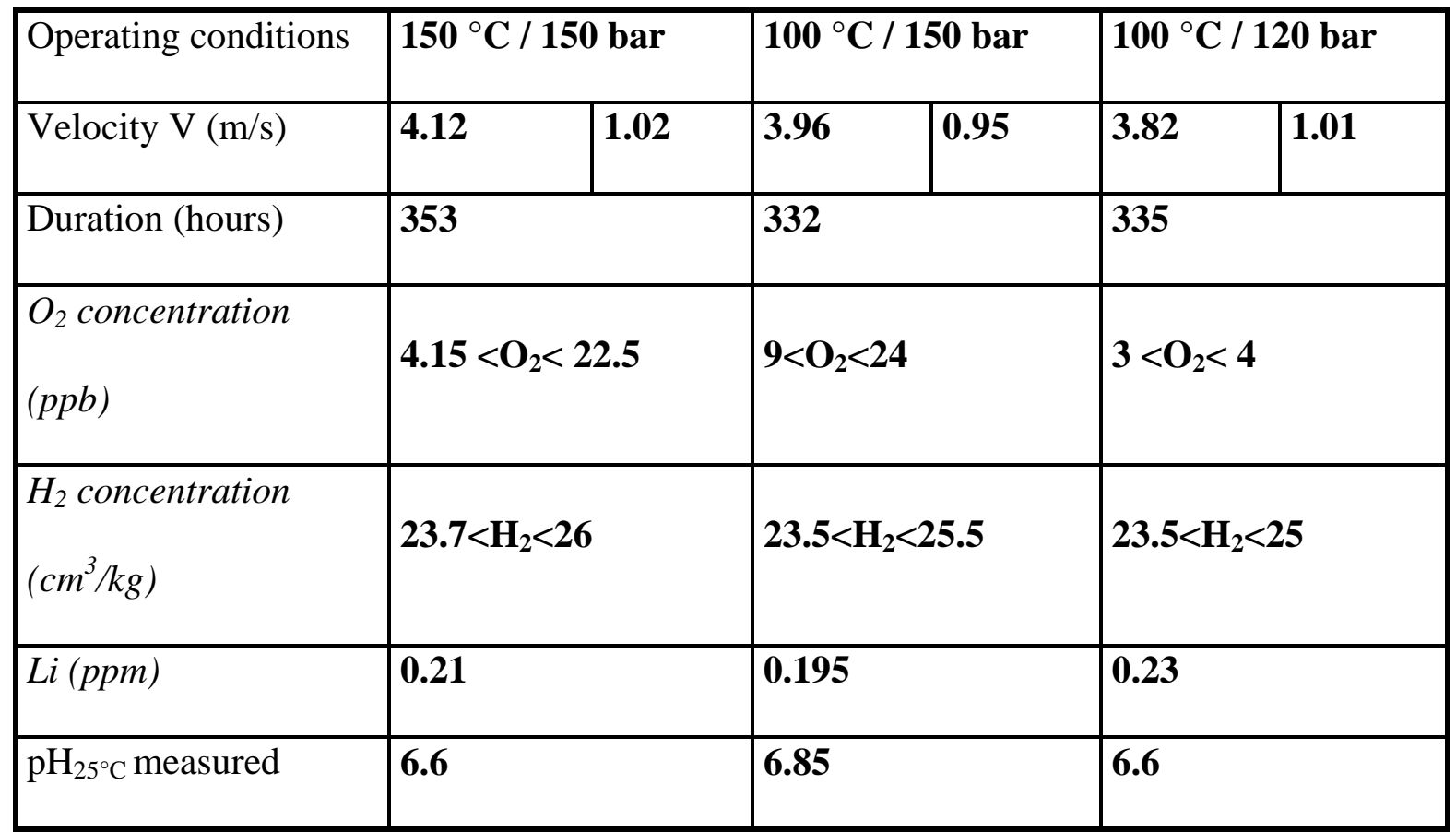


Table 5 - CORELE test - composition of the used SS316L tubes

\begin{tabular}{|c|c|c|c|c|c|c|c|c|c|c|c|c|}
\hline weight \% & $\mathrm{Fe}$ & $\mathrm{Ni}$ & $\mathrm{Co}$ & $\mathrm{Cr}$ & $\mathrm{Mn}$ & $\mathrm{Mo}$ & $\mathrm{Cu}$ & $\mathrm{S}$ & $\mathrm{C}$ & $\mathrm{N}$ & $\mathrm{Si}$ & $\mathrm{P}$ \\
\hline $\begin{array}{c}\text { From } \\
\text { manufacturer }\end{array}$ & 67.4 & 11.2 & 0.093 & 16.77 & 1.640 & 2.06 & 0.29 & 0.007 & 0.012 & 0.070 & 0.440 & 0.031 \\
\hline
\end{tabular}


Table 6-CORELE test - Activation products of the main element of the tubes

\begin{tabular}{|c|c|c|c|c|c|}
\hline Element & $\begin{array}{c}\text { Abundance } \\
(\%)\end{array}$ & $\begin{array}{c}\text { Natural } \\
\text { isotope }\end{array}$ & Reaction & Activation products & $\begin{array}{c}\text { Half-life } \\
\text { (days) }\end{array}$ \\
\hline $\mathrm{Ni}$ & 68 & ${ }^{58} \mathrm{Ni}$ & $(\mathrm{n}, \mathrm{p})$ & ${ }^{58} \mathbf{C o}$ & 71 \\
\hline $\mathrm{Cr}$ & 4.35 & ${ }^{50} \mathrm{Cr}$ & $(\mathrm{n}, \gamma)$ & ${ }^{51} \mathbf{C r}$ & 28 \\
\hline \multirow{2}{*}{$\mathrm{Fe}$} & 0.3 & ${ }^{58} \mathrm{Fe}$ & $(\mathrm{n}, \gamma)$ & ${ }^{59} \mathbf{F e}$ & 45 \\
\cline { 2 - 6 } & 5.8 & ${ }^{54} \mathrm{Fe}$ & $(\mathrm{n}, \mathrm{p})$ & ${ }^{54} \mathbf{M n}$ & 313 \\
\hline
\end{tabular}


Table 7 - CORELE test - Measured release rates

\begin{tabular}{|c|c|c|c|c|}
\hline $\begin{array}{c}\text { Temperature } \\
{ }^{\circ} \mathrm{C}\end{array}$ & $\begin{array}{c}\text { Velocity } \\
\text { m /s }\end{array}$ & Species & $\begin{array}{c}\text { Release rate } \\
\text { ( } \mathrm{mg} / \mathrm{dm}^{2} / \text { month ) }\end{array}$ & $\begin{array}{l}\text { Global release rate } \\
\left(\mathrm{mg} / \mathrm{dm}^{2} / \text { month }\right)\end{array}$ \\
\hline \multirow{6}{*}{150} & \multirow{3}{*}{4.15} & $\mathrm{Ni}$ & $4.7 \pm 0.9$ & \multirow{3}{*}{$22 \pm 3$} \\
\hline & & $\mathrm{Fe}$ & 16. \pm 3 & \\
\hline & & $\mathrm{Cr}$ & $1 \pm 0.4$ & \\
\hline & \multirow{3}{*}{1.03} & $\mathrm{Ni}$ & $8.1 \pm 0.7$ & \multirow{3}{*}{$35 \pm 5$} \\
\hline & & $\mathrm{Fe}$ & $27 \pm 5$ & \\
\hline & & $\mathrm{Cr}$ & $0.27 \pm 0.12$ & \\
\hline \multirow{4}{*}{100} & \multirow[b]{2}{*}{3.98} & $\mathrm{Ni}$ & $<\mathrm{DL}$ & \multirow{2}{*}{$<\mathbf{D L}$} \\
\hline & & $\mathrm{Fe}$ & $<\mathrm{DL}$ & \\
\hline & \multirow[b]{2}{*}{0.99} & $\mathrm{Ni}$ & $0.25 \pm 0.1$ & \multirow{2}{*}{$2.6 \pm 1.3$} \\
\hline & & $\mathrm{Fe}$ & $2.30 \pm 1.3$ & \\
\hline \multirow[b]{4}{*}{100} & \multirow[b]{2}{*}{3.96} & $\mathrm{Ni}$ & $0.5 \pm 0.3$ & \multirow{2}{*}{$0.8 \pm 0.3$} \\
\hline & & $\mathrm{Fe}$ & $0.27 \pm 0.03$ & \\
\hline & \multirow[b]{2}{*}{1.01} & $\mathrm{Ni}$ & $<\mathrm{DL}$ & \multirow[b]{2}{*}{$2.7 \pm 1.5$} \\
\hline & & $\mathrm{Fe}$ & $2.7 \pm 1.5$ & \\
\hline
\end{tabular}

DL : Detection Limit 
Table 8 -CORELE test - Thermal-hydraulic parameters

\begin{tabular}{|c|c|c|c|c|c|}
\hline Inox tube inner diameter & $d_{e}(m)$ & 0.0169 & 0.0169 & 0.0169 & 0.0169 \\
\hline zircaloy insert outer diameter & $\mathrm{d}_{\mathrm{i}}(\mathrm{m})$ & 0.0140 & & 0.0140 & \\
\hline Hydraulic Diameter & $\mathrm{D}_{\mathrm{h}}(\mathrm{m})$ & 0.0029 & 0.0169 & 0.0029 & 0.0169 \\
\hline Surface & $\mathrm{S}\left(\mathrm{m}^{2}\right)$ & 7.04E-05 & 2.24E-04 & 7.04E-05 & $2.24 \mathrm{E}-04$ \\
\hline Flow rate $\left(30^{\circ} \mathrm{C}\right)$ & $\mathrm{Q}\left(\mathrm{m}^{3} / \mathrm{h}\right)$ & 0.972 & 0.768 & 0.972 & 0.768 \\
\hline Test temperature & $\mathbf{T}\left({ }^{\circ} \mathrm{C}\right)$ & 150 & 150 & 100 & 100 \\
\hline Density & $\rho @$ @[test temperature / $150 \mathrm{bar}]\left(\mathrm{kg} / \mathrm{m}^{3}\right)$ & 925 & 925 & 965 & 965 \\
\hline Flow rate [@ test temperature] & $\mathrm{Q}^{\prime}\left(\mathrm{m}^{3} / \mathrm{h}\right)$ & 1.05 & 0.83 & 1.01 & 0.80 \\
\hline Velocity & $\mathrm{V}(\mathrm{m} / \mathrm{s})$ & 4.15 & 1.03 & 3.98 & 0.99 \\
\hline Dynamic viscosity & $\eta(\mathrm{Pa} \cdot \mathrm{s})$ & $1.86 \mathrm{E}-04$ & $1.86 \mathrm{E}-04$ & $2.86 \mathrm{E}-04$ & $2.86 \mathrm{E}-04$ \\
\hline Reynolds Number (Re) & $\operatorname{Re}=\rho \mathrm{VD}_{\mathrm{h}} / \eta$ & $5.98 \mathrm{E}+04$ & $8.64 \mathrm{E}+04$ & $3.89 E+04$ & $5.62 \mathrm{E}+04$ \\
\hline Prandtl Number (Pr) & $\operatorname{Pr}=\eta C_{p} / \lambda$ & 1.15 & 1.15 & 1.74 & 1.74 \\
\hline $\begin{array}{l}\text { Nusselt Number (Nu) with } \\
\text { annular correction }\end{array}$ & $\begin{array}{l}\mathrm{Nu}_{0}=0.023 \mathrm{Re}^{0.8} \operatorname{Pr}^{0.4} \text { and } \\
N u=N u_{0}\left(1-0.14\left(\frac{d_{i}}{d_{e}}\right)^{0.6}\right)\end{array}$ & 140 & 216 & 118 & 181 \\
\hline
\end{tabular}

